\title{
First record of Sergestes belonging to edwardsii species group (Sergestidae, Crustacea) from the Indian Ocean
}

\author{
FARZANA YOUSUF \& QUDDUSI. B. KAZMI \\ Department of Zoology and Marine Reference Collection and Resource Centre, University of Karachi, Kara- \\ chi-75270,Pakistan; farzanaseth@yahoo.co.in
}

\begin{abstract}
Sergestes edwardsii Kröyer, 1855 species group is composed of 9 species: S. semissis (Burkenroad, 1940); S. gibbilobatus (Judkins, 1978); S. orientalis (Hansen, 1919); S. geminus (Judkins, 1978); S. tantillus (Burkenroad, 1940); S. consobrinus (Milne, 1968) California Current Form; $S$. consobrinus (Milne, 1968) Central Form; S. edwardsii (Kröyer, 1855); S. brevispinatus (Judkins,1978). The bathypelagic shrimps belonging to the genus Sergestes are being studied from the IIOE material for its taxonomy and distribution. Two species, S. brevispinatus (Judkins,1978) and S. edwardsii (Kröyer, 1855), have been collected by the research vessels ANTON BRUNN, ARGO, DIAMANTINA, METEOR, OSHORO MARU and VARUNA in the Indian Ocean for the first time. Sergestes edwardsii is broadly distributed throughout the tropical Atlantic; it occurs from the New Land Plaza, Canada, to the wide of the Great Power of the North; throughout the Caribbean and Gulf of Mexico. Records at high northern latitudes in the Western Atlantic are probably due to transport by the Gulf Stream (Judkins, 1978). In Brazil it occurs in Para, in the Archipelago of Are Peter and Sao Paulo, Great River of North Fermando De Noronho (D'Incao, F., 1995, 1998). Specimens of the present material are housed in the Marine Reference Collection and Resource Centre (MRC\&RC), University of Karachi.
\end{abstract}

Key words: Sergestes edwardsii group, Sergestidae, Indian Ocean Expedition

\section{INTRODUCTION}

The International Indian Ocean Expedition (IIOE) 1960-65 obtained a large collection of sergestids. The basic information on the systematic biology and ecology of planktonic shrimps in the Indian Ocean is limited. Also, there are some groups of marine organism that remain poorly studied due to taxonomic difficulties. The large family Sergestidae is one of these groups. Important contributions on the systematics of this family are: A. Milne-Edwards (1830); Kröyer (1859); Smith (1882-86); Bate (1888); Wood-Mason 